\title{
SEMA3D wt Allele
}

National Cancer Institute

\section{Source}

National Cancer Institute. SEMA3D wt Allele. NCI Thesaurus. Code C131514.

Semaphorin-3D (777 aa, $\sim 90 \mathrm{kDa}$ ) is encoded by the human SEMA3D gene. This protein plays a role in the negative regulation of axon migration. 